DOI 10.15826/qr.2016.2.166

УДК 821.111Лайвли-31+821.111Фицджеральд-31+821.111Данмор-31

\title{
IMAGES OF THE RUSSIAN PEOPLE AND RUSSIA IN THE CONTEMPORARY ENGLISH NOVEL ${ }^{\star}$
}

\author{
Olga Sidorova \\ Ural Federal University, \\ Yekaterinburg, Russia
}

The mythological image of Russia in English fiction has been shaped and repeated over the course of many centuries. Russia was traditionally viewed as a distant, cold, unpredictable, and wild country. The aim of the article is to examine a new Russian cultural discourse that first appeared in English fiction in the early twentieth century and developed during the last decades of the twentieth and the first decade of the twenty-first centuries. Russia's history in the twentieth century had a powerful impact on Russian themes in English literature. To prove this point, novels by three contemporary female English writers are analysed. In Penelope Lively's The Moon Tiger (1987), Penelope Fitzgerald's The Beginning of Spring (1988), and Helen Dunmore's The Siege (2001) and The Betrayal (2011), Russian history is viewed sympathetically through the dramatic fates of normal people. The characters break down stereotypes and create a complex image of Russia and its people in contemporary English fiction.

Keywords: Russian themes; stereotypes; mythological images; cultural discourse; history; the contemporary English novel.

Мифологизированный образ России в английской художественной литературе сформировался и постоянно используется в течение нескольких столетий. Традиционно Россия описывается как далекая, холодная, непредсказуемая и дикая страна. Цель данной статьи - продемонстрировать динамику нового дискурса, а именно дискурса русской культуры в английской литературе, который возник в начале XX в. и получил дальнейшее развитие в литературе конца XX - начала XXI в. Особо подчеркивается влияние трагической истории России XX в. на изменение модуса русской темы в английской литературе. Русская тема в современном английском романе впервые в отечественном литературоведении рассматривается на примере произведений трех английских писатель-

* Citation: Sidorova, O. (2016). Images of the Russian People and Russia in the Contemporary English Novel. In Quaestio Rossica, Vol. 4, № 1, p. 183-194. DOI 10.15826/qr.2016.2.166.

Цитирование: Sidorova O. Images of the Russian People and Russia in the Contemporary English Novel // Quaestio Rossica. Vol. 4. 2016. № 1. P. 183-194. DOI 10.15826/qr.2016.2.166.

(C) Sidorova O., 2016

Quaestio Rossica • Vol. 4 • 2016 • № 2, p. 183-194 
ниц: «Лунный тигр» Пенелопы Лайвли (1987), «Начало весны» Пенелопы Фицджеральд (1988), «Блокада» и «Измена» Хелен Данмор (2011). История России преломляется в этих романах в судьбах простых людей, образы которых создаются авторами с явным состраданием и симпатией. Рассматриваемые произведения ломают сложившийся в английской литературе стереотип, создавая новый дискурс сочувствия к России и трагическим судьбам русских людей в ХХ в.

Ключевые слова: русская тема; стереотип; мифологический образ; дискурс культуры; история; современный английский роман.

Both Russian and English critics and scholars have studied images of the Russian people and Russia in English fiction. Research of this kind, as well as studies of the literary and cultural representations of various Others, became increasingly popular in the last decades of the twentieth century. These themes have been examined from comparative, imago logical, and post-colonial perspectives, to name just a few. According to R. Marsh, the "real West, real Russia include among other components imaginary realities"1: these realities were created, rooted, and supported in the public imagination by fiction, among other influential sources.

In her classic study The Image of Russia in English fiction of the IX-XIX Centuries, N. P. Mikhalskaya has convincingly showed that although Russian themes have been constantly used in English fiction, they have been quite stable and have not undergone visible changes [Михальская]. Асcording to Mikhalskaya, the image of Russia and its people in English fiction before the end of the nineteenth century can be described as mythological, since it was characterised by a set of distinct binary oppositions, the components of which were not used separately. Furthermore, the mythological image of Russia in English fiction demonstrates a high level of repeatability its structure has remained virtually unchanged and unchangeable for several centuries, a fact which Mikhalskaya clearly illustrates with numerous examples and textual analyses.

To support the point, we should also mention A. Cross' The Russian Theme in English Literature from the Sixteenth Century to 1980. An Introductory Survey and a Bibliography. This work includes a bibliography of English fiction from 1587 to 1980 that deals with Russian themes: there are 1,072 books altogether, and every book title is accompanied by a brief annotation of two or three lines. These titles and annotations lead to a number of conclusions. The author stresses that the bibliographical list "is an attempt to show the extent to which involvement with the Russian theme is not a new fashion but a long-established tradition in English literature, impressive quantitatively, if not always qualitatively" [Cross, p. 2]. True, images of Russia and its people have not often been leading themes in serious English literature, but they were quite popular in mass literary genres, such

\footnotetext{
${ }^{1}$ In the original: «Реальный Запад, реальная Россия - это еще и реальность образных представлений о них» [Марш, с. 12].
} 
as "historical novels with settings from the eighteenth century to the October Revolution, novels of contemporary Soviet life, of the fortunes and fates of emigres, spy stories, high adventure, lust romance" [Ibid., p. 8]. 19 books dealing with Russian themes were published in Britain in 1980, among which were the following:

N 1054 K. Amis. Russian hide and seek. Set in 2030, fifty years after Soviet takeover of Britain; ... N 1056 B. Bainbridge. The winter garden. Black comedy of cultural trip to the Soviet Union; ...N 1059 G. Butler. The red staircase. Scottish heroine goes to Russia as companion to aristocratic family on eve of Revolution; ...1061 J. Gardner. Golgotha. Soviet invasion of Britain; ... N 1066 J. Le Carre. Smiley's people. Spy thriller; N 1067 C. MacArthur. The flight of the dove. Love affair of Englishman and leading Soviet gymnast, who dies while performing in Moscow Olympics; ... N 1069 J. Marton. The Janus pope. Soviet plot to replace pope by his communist brother; N $1070 \mathrm{~W}$. H. Mefford. The games of 80. Olympic games thriller [Ibid., p. 207-208].

This list demonstrates the state and direction of public anxiety and fear. Russia is viewed, primarily, as a source of danger, as a political and military rival, or, at best, as an inexplicable and incomprehensible world where an Englishman easily gets lost, as indeed happens to the main character in Beryl Bainbridge's novel The Winter Garden.

A number of twenty-first century studies conducted by Russian scholars clearly show that the same stereotypical and mythological image of Russia is still employed in British literature, though some new overtones have appeared [см.: Бреева, Хабибуллина; Хабибуллина; Королева]. Thus, along with the conventional civilisational and political discourses that Lilya Khabibullina mentions, there is a cultural discourse that implies "a right for some Russian people to enjoy sympathy (from the British side. - O. S.) since they clearly belong to the world of European culture" [Хабибуллина, с. 230].

The qualitatively new developments in the image of Russia and its people in British fiction can be said to have originated during the second half of the twentieth century. Analysing the reception of this phenomenon at the end of the twentieth century, T. Krasavchenko has persuasively demonstrated that the old mythological approach has come to co-exist with a newer one in serious and popular fiction, in travelogues, and even in nonfiction. The scholar concludes that ambiguity has become a characteristic feature of English literature when dealing with Russian themes. What is more, "Russia's reputation as a great country is saved by its literature and, by extension, its culture" [Красавченко].

The aim of our article is not just to support this point, but also to add a historical perspective to the Russian discourse in contemporary English literature. What is more, for the first time in Russian academic criticism, novels by three female English writers (Penelope Lively, Penelope Fitzgerald, and Helen Dunmore) will be discussed in terms of their perspectives on Russia and its people. 
It is not only Russian culture that has provided a solid base for a sympathetic approach to the country: the suffering that millions of Russians endured during the twentieth century has also contributed. Thus, Russia's historical development is conceived not only as a source of danger for the outer (presumably civilised) world, but also as the manifestation of a Russian holocaust ${ }^{2}$.

Thus, the writer and historian Claudia Hampton, the main character of Penelope Lively's 1987 Booker-winning novel The Moon Tiger, often speculates sympathetically on Russia's tragic experience in the recent past. Claudia considers the Russian people to be "the most tormented people in the world... Somewhere... are whispers of St Petersburg, of the Crimea, of Pushkin, of Turgenev, of million upon million enduring peasants, of relentless writers and parched summers, of the most glorious language ever spoken, of samovars and droshkys, and the sad sloe-eyed faces of a thousand icons" [Lively, p. 61-62]. Along with traditional stereotypical components (peasants, samovars, icons, 'barbaric' names), Claudia also recollects the millions of Russians who died on the battlefields of the Second World War, in Nazi camps, and in besieged Leningrad: she remembers "the Russian prisoners herded into open-air pens and left till they died either of cold or starvation; the furnace of Stalingrad; the thirty destroyed cities" [Lively, p. 67]. One of the novel's minor characters, a Russian aristocratic emigrant, is depicted as an extremely unpleasant person, despite the long-established tradition of portraying similar such individuals positively: "Sasha... to have been an excellent reason for the Russians to have a revolution: a man of total moral fecklessness who never did a day's work in his life and disposed of the family fortunes... before he was thirty" [Lively, p. 62].

During the last decades of the twentieth and the first decade of the twenty-first centuries, a number of outstanding novels either set in Russia or depicting Russian characters were published in Britain: P. Fitzgerald's The Beginning of Spring (1988), M. Amis' House of Meetings (2006), H. Dunmore's The Siege (2001) and The Betrayal (2010), A. D. Miller's Snowdrops (2011), and others. ${ }^{3}$

Undoubtedly, every book mentioned above is worth a deep reading and thorough analysis. The novels in question belong to different genres and the authors employ various techniques and perspectives, but they all share an interest in Russia and its people, one which is quite often sympathetic. It has been suggested that the well-rooted myth of Russia has undergone a certain transformation in these books, one which is connected with the changing historical and cultural situation, as well as with the search for a new British new identity [см.: Бреева, Хабибуллина].

${ }^{2}$ In his novel The White Hotel (1981), D. M. Thomas follows his heroine, a Russian woman called Liza, from her youth in Vienna to Babi Yar, where she was killed by the Nazis in a massacre. In his other novels, Thomas also writes of the tragic history of the Russian peasantry, of the suffering of GULAG prisoners, and of the Stalinist regime that brought immense troubles to the Russian people. Thomas' books have been studied by T. Krasavchenko [см.: Красавченко].

${ }^{3}$ A much longer list of books is given by T. Krasavchenko [Красавченко]. We have extended this list by adding the novels that we analyse, but were not already mentioned. 
Penelope Fitzgerald (1916-2000), who never visited Russia, wrote her novel The Beginning of Spring in 1988. The novel is set in Moscow in 1913. There are both English and Russian characters in the novel. The central figure is the Russian-born Englishman Frank Reid (Frank Albertovich, as Russian characters call him), a printer and the owner of the Reid Press: he is surrounded by his children, English relatives, Russian and English colleagues, employees, business partners, and servants, and friends and acquaintances. Everyone goes about his or her own life: family troubles go hand in hand with political and business problems. In this world, a new Russian nurse for the Reid children is much more preferable to an English governess. A critic writes: "A middle-class British family is domiciled in a most un-British country, in this case, Russia" [Plunket, p. 1]. Comparing The Beginning of Spring with E. M. Forster's novel A Passage to India (a British community abroad is depicted in both novels), R. Plunket states that while those of E. M. Forster's characters who belong to different nations and social strata are strictly separated, P. Fitzgerald's characters are socially and emotionally equal and live together. In many ways, her novel can be viewed as a comedy of manners. On the first page of the book, Frank's wife Nellie leaves the family house on ' 22 Lipka Street in the Khamovniki district' in order to abandon her family, and on the very last page she returns. The last sentence of the book is as follows: 'He opened the door, and Nellie walked into the house' [Fitzgerald, p. 1, 246]. The whole book takes place between these two sentences.

Many characters in the novel support this comedy of manners: they are numerous, picturesque, and unique. One of them is Selwyn Crane (Selwyn Osipych to the Russian employees), the managing accountant of the Reid Press. He is a follower of Tolstoy and a poet who published a collection of poems entitled "Birch Tree Thoughts" ("Frank expected Russian poetry to be about birch trees and snow, and in fact in the last verses Selwyn had read to him birch trees and snow were both mentioned pretty frequently") [Fitzgerald, p. 5]. The very appearance of Selwyn demonstrates a peculiar mix of tastes and cultures: "With a kind of black frock-coat he wore a pair of English tweed trousers, made up by a Moscow tailor who had cut them rather too short, and a high-necked Russian peasant's blouse, a tribute to the memory of Lev Nikolaevich Tolstoy" [Fitzgerald, p. 8]. Some of the characters seem to have come straight out of classic Russian literature, like Frank's business partner Kuriatin, a rich merchant and bon vivant. $\mathrm{He}$ is reminiscent of Alexander Ostrovsky's Volodya, a student and a political activist (one more student to join the hundreds from the classics of nineteenth-century Russian literature) who used to work a hand press and wrote a treatise on "universal pity". The same can be said of Frank's brotherin-law Charlie (another funny-foreigner-in-Russia caricature), who arrives from England to help with the family's problems and gets acquainted with traditional Russian hospitality: lavish food and drink, the banya, samovars, gypsies, snow, and troikas. It is little wonder that Charlie leaves Russia totally enchanted. 
Given postmodernism's predominance in literature, this novel could be taken as a rather old-fashioned piece, but the atmosphere created in the book is definitely unique. Fitzgerald not only writes the story of a family: she also recreates the atmosphere of old Moscow and old Russia, a world full of names, details, and cultural references. Extremely warm and nostalgic, the world echoes with the best images of pre-revolutionary Russia and classic Russian culture:

Frank's affection for Moscow came over him at odd and inappropriate times and in undistinguished places. Dear, slovenly mother Moscow, bemused with the bells of its four times forty churches, indifferently sheltering factories, whore-houses and golden domes, impeded by Greeks and Persians and bewildered villagers and seminarists straying on to the tramlines, centered on its holy citadel, but reaching outwards with a frowsty leap across the boulevards to the circles of workers' dormitories and railheads, where the monasteries still prayed, and at last to a circle of pig-sties, cabbage-patches, earth roads, earth closets, where Moscow sank back, seemingly with relief, into a village [Fitzgerald, p. 41-42].

What is more, the novel is extremely informative not only from a cultural perspective, but also from an historical and factual point of view. This is the quality specifically mentioned by Julian Barnes in his enthusiastic review: "Many readers' initial reaction to a Fitzgerald novel... is, 'But how does she know that?' How does she know... about methods of bribing the police in pre-revolutionary Moscow, and about techniques of printing?..” Barnes also mentions that, despite the abundance of facts, the novel is compact and never boring. Comparing novels with cities, the critic states that "the subtler, wiser ones, offer no... immediately readable route maps. Instead of a journey through the city, they throw you into the city itself, and life itself: you are expected to find your own way" [Barnes, p. 9, 13].

The entirety of Russia's turbulent twentieth century can be read in the novel, although the action only takes place across several months: in contrast to the novel's characters, its readers are well aware of the finiteness of this world and way of life, of the fact that they came to a definite end in 1917. Thereby, it is obvious that Fitzgerald actively involves the horizons of readers' expectations: historical meaning is flexible, allowing the reader to interpret and evaluate it [Яусc]. Barnes wisely observes that "the absentee author has the confidence to presume that the reader might be as subtle and intelligent as she is" and will be able "to work the novel out" [Barnes, p. 14]. Thus, seen retrospectively, the comedy of manners transforms into a drama, or even a tragedy, about twentieth-century Russia: it thereby acquires nostalgic overtones for the world that has been lost.

From a Russian reader's point of view, the novel is nearly devoid of the tall tales that are almost inevitable when a foreign author describes a country that they have never visited. Only a few names might seem peculiar to the Russian reader (for example, Lisa Ivanovna and Volodya Vasilich, where 
patronymics curiously follow diminutives). What is more, the only inarticulate and confusing character is Lisa Ivanovna, the Russian governess of the Reid children, who, in the context of the novel, is viewed as an image of Russia itself. Lisa suddenly and almost inexplicably disappears both from the life of the family at the end of the book. The scene of her disappearance (the epiphanic scene, according to Barnes) is portrayed from the perspective of a child (Dolly, Frank's eldest daughter), and suggests a number of potential interpretations. However, all of the interpretations "are possible and, mysteriously, not incompatible with each other” [Barnes, p. 12].

Helen Dumnore's The Siege (2001) and The Betrayal (2010) are a significant and in many ways unique contribution to the Russian discourse in contemporary British fiction. Dunmore (b. 1952), a well-known British novelist, poet, and children's writer, is also a scholar and a literary critic. Her lifelong love of Russian culture, literature, and history clearly shows in her novels. Her broad preoccupation with Russia is based on the writer's deep knowledge of the Russian classics:

I read a lot of Russian fiction and poetry. Osip Mandelstam was one of the strongest influences on me; some of his poems are like talismans that you carry around with you. I don't suppose you can write a novel about Russian wartime without thinking a great deal about Tolstoy. I'm always thinking about his books [McCrum].

Episodes from World War II are a popular theme in British fiction, but few of them depict the Soviet theatre of conflict, especially on a personal and sympathetic level. In her 2001 interview with The Guardian, Dunmore states:

It struck me that the Russian experience of war has still not been fully told here. $\langle\ldots\rangle$ We have a lot of films glorifying the Western contribution to the war, but on the other side there is this huge canvas of what happened in Russia which still deeply marks that land, deeply marks those people [McCrum].

Dunmore's The Siege, wholly devoted to the first year of the Leningrad siege, clearly stands apart from many other British novels on Russia: according to A. Anichkin, it is one of the few books to depict Russia, its people, and its history in a favourable tone and with a sense of historical optimism [Аничкин].

The author depicts the siege through the fates and lives of a group of ordinary people: the citizens of Leningrad. Dunmore declares: "What I wanted to do by writing the novel was to focus on this small group of people and to create a world which is felt and tasted and rooted. It's not an overview of the siege, it's an inner view" [McCrum]. There are no English or foreign characters in the novel, which is very atypical for a contemporary Western novel on Russia: Anichkin has ironically remarked that the only Englishman in the novel is William Shakespeare, whose books are read aloud by the Russian characters. 
We can definitely state that the descriptions of the besieged city are heavily based on documentary sources and stories of real blockadniks, the people who survived all 871 days of the terrible siege. More than half a million of people died of starvation alone, not to mention bombings and battles. Dunmore has stated:

One thing that struck me very much with memoirs of people who lived through the siege was the gradual freezing of everything and the cessation of things. Although there was this disruption, this panic of blockade, there was the sense that the water stopped running, the trams stopped running and families and individuals retreated deep into themselves. Into their cells, the cell of their personality or their room. I wanted to get that quality of isolation and fear, the terror of dying alone and nobody even knowing, which is what happened to a lot of people [McCrum].

The novel describes the process whereby life in the besieged city gradually slips into darkness and freezes: it looks quite convincing to Russian readers, who are well aware of this historical period thanks to the use of the Leningrad blockade in Soviet and Russian war epics. The Russian characters of the novel are Leningrad citizens from different generations whose lives before the war were never easy because of private troubles, the wretched quality of daily life, and the pressure of Stalin's totalitarian regime. The war brings a new reality full of bombings, death, starvation, and decay, but it fails to kill human relationships and hope. The characters are eager to love, to take care of the weak, and to help each other, even in seemingly inhuman situations. Marina, a retired ballet dancer, and Mikhail, an elderly writer, sacrifice their lives to save the younger characters, Andrei, Anna, and her five-year-old brother Kolya, all of whom manage to survive. The novel's final scene is an apotheosis of life and hope: having survived the first and the most terrible winter of the blockade, Anna, Andrei, and Kolya are walking along one of the beautiful embankments of the great and unconquered city: "They are... out for a walk on this beautiful May afternoon, as Leningrad settles like a swan on the calmest of waters" [Dunmore, 2001, p. 291].

The novel's exit line is a quotation from Alexander Pushkin's famous poem Monument: Dunmore gives it both in Russian and in her own English translation:4““ 'Нет, весь я не умру...' ('No, I shall not wholly die ...') Alexander Pushkin” [Ibid, p. 292].

The novel is followed by a select bibliography, where the Russian classics (works by Alexander Pushkin, Anna Akhmatova, Marina Tsvetayeva, Nikolai Gumilev, and others) occupy an honourable place.

In The Betrayal, the author follows the post-war lives of the main characters from The Siege (Anna, Andrei, and Kolia). As Dunmore has declared, she is primarily interested in the history of ordinary people who endure their country's "great" history, "people who immerse in

${ }^{4}$ All quotations from Pushkin in the novel, and there are quite a few of them, were made by the author. 
history" [Hay Festival yesterday]. She believes that a book of fiction is able to make the reader return to a concrete historic moment while still carrying their knowledge of future events. The novel is set in the postwar Leningrad of 1952-1953: the citizens have not yet fully overcome the terrors of the blockade, life is hard, and Stalin's regime is full of terror, arrests, and purges. This is the period of the notorious Doctors' Case, when medical professionals were accused of plotting against Party leaders and arrested en masse both in Moscow and Leningrad. Andrei, a talented young doctor, is ordered to treat Gorya, the young son of a highly-ranked NKVD (secret police) officer. ${ }^{5}$ Gorya is incurable, so Andrei is arrested. A Russian reader will be familiar with many of the historical details and mores both from books and the memories of witnesses (national genetic memory), but it is hard to predict an English reader's reaction. However, Dunmore never leaves her readers in an existential deadlock. Along with horror, betrayal, and fear, the world of the novel is full of humanity, sympathy, love, and hope, both for its characters and its readers.

After Andrei has been arrested, Anna gives birth to their daughter whom she symbolically names Nadezhda (the Russian word for 'hope'). Memory links the characters of the novel and different eras. While listening to the radio announcement of Stalin's death, Anna thinks that her memories of the passing epoch will be valuable for coming generations, especially her daughter. Her father's diaries are hidden underground in the garden of Anna's summer house; thus, she is already keeping his memories, which is dangerous enough (her father was a victim of Soviet political repression). To keep her own memories alive, Anna decides to make a series of drawings: "You need only draw the smallest things. Not the whole world, don't try for that. $<\ldots>$ She will draw every day. There will be a record" [Dunmore, 2011, p. 325].

One more source of hope and strength for the characters is Russia itself - its space and its people. Andrei, a Siberian-born man on his way into Siberian exile, clearly understands this fact:

At that moment Andrei remembers the smell that filled his nostrils before, when he pressed them to the gap where icy air poured in. It seemed all the sharper in contrast to the fetid air of the cattle car. His brain comes alive, remembering, recognizing. It was the smell of the taiga. It was the cold, wild air of home [Ibid, p. 313].

It would be an exaggeration to think that Dunmore's Russian novels attract an English-reading audience only because they give glimpses into the dark depths of Soviet history, although this cannot but draw their attention. Many non-fiction books and memoirs about the siege of Leningrad and Stalin's regime have been translated into English in recent years: some of

\footnotetext{
${ }^{5}$ Gorya is, again, a strange-sounding name to the Russian ear: it is presumably a diminutive, but we are never informed about the boy's full name.
} 
them are mentioned in Dunmore's own Bibliographies. However, Dunmore's characters, all of whom are well rounded and unconventional, have the power to change the attitudes of a British audience. Even Gorya's father, the terrible, powerful, and utterly corrupt NKVD officer Volkov ('wolf' in Russian) is not totally two-dimensional: he is obliged to participate in an official party that resembles an orgy, drink heavily, and dance the Krasnyi Yar when his only son is dying. ${ }^{6}$

It is certain that Helen Dunmore's Russian novels are unique: her perspective on the country, its history, and its people clearly opposes the portrayals providedbymanyotherwriters. In 2011,Snowdrops, adebutnovelby A. D. Miller, was included in the Man Booker prize shortlist and thus attracted the attention of many readers. Miller, who worked in Moscow as a correspondent for The Economist for three years, relates a story about an English banker Nick, who recollects his Moscow adventures in 2001-2. The book's epigraph reads as follows: "Snowdrop: 1. An early-flowering bulbous plant, having a white pendent flower. 2. Moscow slang. A corpse that lies buried or hidden in the winter snows, emerging only in the thaw" [Miller, 2011, p. 3].

The epigraph immediately immerses the reader into a fresh and original atmosphere, which is the novel's most attractive feature:

Surely the greatest aspect of Snowdrops is the picture of Moscow in the first years after the turn of the century, that mix of the awful and the awe-inspiring (sometimes in the same moment). This aspect makes its way into Nick's tone and his attraction to Moscow is compelling and believable and does a much better job explaining his character than anything else in his "confession" [O’Connell].

This mix is, nevertheless, dominated by the criminal element: "In Russia there are no business stories. And there are no politics stories. There are no love stories. There are only crime stories" [Miller, 2015]. As John O'Connell, The Guardian reviewer, sarcastically remarks, "this would have been news to Tolstoy and Chekhov. But times have changed, and Russia's position on the world stage is such that you can say whatever you like about it, thanks to a widespread willingness to believe the very worst" [O'Connell]. Here, O'Connell precisely defines the prevailing attitude of many contemporary British authors towards Russian themes, an attitude shaped by well-rooted traditions and contemporary politics.

Dunmore's point of view on Russian history is also opposed to that of Antony Beevor, a well-known English writer and historian, as their discussion at the Hay Literary Festival shows. Beevor's works, particularly his non-fiction book Berlin. The Downfall 1945 [Beevor], made a visible impact on Martin Amis in his assessment of the role and actions of the Soviet Army in World War II in his novel House of Meetings (2006). However, the three female English

${ }^{6}$ Although the term Krasnyi Yar sounds like an authentic Russian dance, it will be completely unfamiliar to Russian readers. 
writers who have created works where Russian themes are either touched upon (Penelope Lively) or discussed in detail (Penelope Fitzgerald and Helen Dunmore) clearly demonstrate a new approach. Within the framework of a broad cultural discourse, these women have conducted a deeper investigation into the dramatic history of the country through the fate of its common people. We can state that a new discursive approach has been created, one that is constituted by sympathy for the country's tragic history and for the complexity and ambiguity of the Russian national character. They clearly break with literary and public stereotypes and change the prevailing perspective. All threeauthorsaredeeplyinterestedinclassicalRussian culture, literature, andarts: they are looking for the reflected gleam of this culture in the fates and characters of the Russian people.

\section{Список литературы}

Аничкин A. Ленинград: «нет, весь я не умру...» // Тетрадки: что о нас думают в Европе. URL: http://european-book-review.blogspot.com/2006_11_01_archive.html (дата обращения: 15.09.2015).

Бреева Т. Н., Хабибуллина Л. Ф. Национальный миф в русской и английской литературе. Казань : РИЦ «Школа», 2009. 612 с.

Королева С. Б. Миф о России в британской литературе и культуре (до 1920-х годов). Ниж. Новгород : Радонеж, 2012. 256 с.

Красавченко T. Н. Восприятие России и русских в английской литературе на рубеже XX-XXI веков // Новые российские гуманитарные исследования. 2008. № 3. URL: http://www.nrgumis.ru/articles/134 (дата обращения: 15.09.2015).

Мари Р. Россия и Запад в исторической перспективе // Россия и Запад в начале нового тысячелетия / отв. ред. А. Ю. Большакова. М. : Наука, 2007. С. 11-39.

Михальская Н. П. Образ России в английской художественной литературе IX-XIX веков. М. : Лит. ин-т им. А. М. Горького, 2003. 132 с.

Хабибуллина Л. Ф. Миф России в современной английской литературе. Казань : Изд-во Казан. ун-та, 2010. 205 с.

Яycc X. P. К проблеме диалогического понимания. URL: http://www.bim-bad.ru/ biblioteka/article full.php?aid=1228 (дата обращения: 20.09.2015).

Barnes J. The Deceptiveness of Penelope Fitzgerald // Barnes J. Through the Window. N. Y. : Vintage Intern., 2012. P. 1-14.

Beevor A. Berlin : The Downfall 1945. L. : Penguin Books, 2002. 552 p.

Cross $A$. The Russian Theme in English Literature from the Sixteenth Century to 1980 : An Introductory Survey and a Bibliography. Oxford : Oxford University Press, $1985.278 \mathrm{p}$.

Dunmore H. The Siege. L. : Penguin Books, 2001. 312 p.

Dunmore H. The Betrayal. L. : Penguin Books, 2011. 328 p.

Fitzgerald P. The Beginning of spring. L. : Flamingo, 2003. 246 p.

Hay Festival yesterday : Helen Dunmore and Antony Beevor speak history // Guardian. June, 01, 2010. URL: http://www.guardian.co.uk/books/booksblog/2010/jun/01/hay- festival-yesterday (mode of access: 15.09.2015).

Lively P. Moon Tiger. L. : Penguin Books, 2006. 208 p.

$M c$ Crum R. The Siege is a novel for now. Interview with Helen Dunmore // Guardian. June, 10, 2001. URL: http://www.theguardian.com/books/2001/jun/10/fiction.features3 (mode of access: 15.09.2015)

Miller A. D. Snowdrops. N. Y. : Doubleday, 2011. 262 p.

Miller A. D. Snowdrops. URL: http://www.admillerbooks.com/book/snowdrops/home (mode of access: 15.09.2015)

O'Connell J. Snowdrops by A. D. Miller - review. URL: http://www.theguardian.com/ books/2011/jan/01/snowdrops-a-d-miller-review (mode of access: 20.09.2015).

Plunket R. Dear, slovenly Mother Moscow // The New-York Times. May, 7, 1989. URL: http://www.nytimes.com/1989/05/07/books/dear-slovenly-mother-moscow.html?ref (mode of access: 05.09.2015). 


\section{References}

Anichkin, A. (n. d.). Leningrad: "Net, ves' ya ne umru..." [No, I shall not wholly die...]. In Tetradki: Chto o nas dumayut v Evrope. URL: http://european-book-review. blogspot.com/2006 1101 archive.html (mode of access: 15. 09. 2015).

Barnes, J. (2012). The Deceptiveness of Penelope Fitzgerald. In Barnes, J. Through the Window (pp. 1-14). N. Y., Vintage Intern.

Beevor, A. (2002). Berlin. The Downfall 1945. 552 p. L., Penguin Books.

Breeva, T. N. \& Khabibullina, L. F. (2009). Natsional'nyy mif $v$ russkoy $i$ angliyskoy literature [National Myth in Russian and English Literature]. 612 p. Kazan, RITs "Shkola".

Cross, A. (1985). The Russian Theme in English Literature from the Sixteenth Century to 1980. An Introductory Survey and a Bibliography. 278 p. Oxford, Oxford University Press.

Dunmore, H. (2001). The Siege. 312 p. L., Penguin Books.

Dunmore, H. (2011). The Betrayal. 328 p. L., Penguin Books.

Fitzgerald, P. (2003). The Beginning of spring. 246 p. L., Flamingo.

Hay Festival yesterday: Helen Dunmore and Antony Beevor speak history (2010). In Guardian, June 1. URL: http://www.guardian.co.uk/books/booksblog/2010/jun/01/ hay-festival-yesterday (mode of access: 15.09.2015).

Khabibullina, L. F. (2010). Mif Rossii v sovremennoy angliyskoy literature [The Russian Myth in Modern English Literature]. 205 p. Kazan, Kazansky universitet.

Koroleva, S. B. (2012). Mif o Rossii v britanskoy literature $i$ kul'ture (do 1920kh godov) [The Russian Myth in British Literature and Culture (before the 1920s) ]. 256 p. Nizhniy Novgorod, Radonezh.

Krasavchenko, T. N. (2008). Vospriyatie Rossii i russkikh $v$ angliyskoy literature na rubezhe XX-XXI vekov [The Perception of Russia and Its People in English Literature in the Late $20^{\text {th }}$ - Early $21^{\text {st }}$ Centuries]. In Novye rossiyskie gumanitarnye issledovaniya, 3. URL: http//www.rngumis.ru (mode of access: 15.09.2015).

Lively, P. (2006). Moon Tiger. 208 p. L., Penguin Books.

Marsh, R. (2007). Rossiya i Zapad v istoricheskoy perspective [Russia and the West in the Historical Perspective]. In Bol'shakova, A. Yu. (Ed.). Rossiya i Zapad v nachale novogo tysyacheletiya (pp. 11-39). Moscow, Nauka.

McCrum, R. (2001). The Siege Is a Novel for Now : Interview with Helen Dunmore. In The Guardian, June 10. URL: http://www.theguardian.com/books/2001/jun/10/fiction. features3 (mode of access: 15.09.2015).

Mikhal'skaya, N. P. (2003). Obraz Rossii v angliyskoy khudozhestvennoy literature $I X-X I X$ vekov [The Image of Russia in the English Fiction of the $9^{\text {th }}-19^{\text {th }}$ Centuries]. $132 \mathrm{p}$. Moscow, Literaturnyy institut im. A. M. Gor'kogo.

Miller, A. D. (2011). Snowdrops. 262 p. N. Y., Doubleday.

Miller A. D. (n. d.). Snowdrops. URL: http://www.admillerbooks.com/book/snowdrops/home (mode of access: 15.09.2015).

O'Connell, J. (n. d.). Snowdrops by A. D. Miller - review. URL: http://www.theguardian.com/books/2011/jan/01/snowdrops-a-d-miller-review (mode of access: 20.09.2015).

Plunket, R. (1989). Dear, slovenly Mother Moscow. In The New-York Times, May 7. URL: http://www.nytimes.com/1989/05/07/books/dear-slovenly-mother-moscow.html?ref (mode of access: 05.09.2015).

Jauss, H. R. (n. d.). K probleme dialogicheskogo ponimaniya [Question and Answer: Forms of Dialogic Understanding]. URL: http://www.bim-bad.ru/biblioteka/article_full. php?aid=1228 (mode of access: 20.09 .2015$)$.

The article was submitted on 28.04.2016 